\title{
Crystal structure, infrared and Raman spectra of tripotassium trisaccha-rinate dihydrate, $\mathrm{K}_{3}\left(\mathrm{C}_{7} \mathrm{H}_{4} \mathrm{NO}_{3} \mathrm{~S}\right)_{3} \cdot 2 \mathrm{H}_{2} \mathrm{O}$
}

\author{
Gligor Jovanovski ${ }^{1 *}$, Branko Kaitner ${ }^{\dagger}{ }^{\dagger}$, \\ Orhideja Grupce ${ }^{1}$, Pance Naumov ${ }^{1}$ \\ 1 Institute of Chemistry, Faculty of Science, \\ The "Sv. Kiril \& Metodij" University, P.O. Box 162, MK-1001 Skopje, Macedonia \\ 2 Laboratory of General and Inorganic Chemistry, Faculty of Science, \\ University of Zagreb, HR-10000 Zagreb, Ul. kralja Zvonimira 8, Croatia
}

Received 3 October 2003; accepted 25 November 2003

\begin{abstract}
The crystal structure of tripotassium trisaccharinate dihydrate, $\mathrm{K}_{3}\left(\mathrm{C}_{7} \mathrm{H}_{4} \mathrm{NO}_{3} \mathrm{~S}\right)_{3} \cdot 2 \mathrm{H}_{2} \mathrm{O}$, is triclinic, space group $P \overline{1}, Z=2$. It consists of three crystallographically independent potassium and saccharinato ions as well as two structurally different water molecules. Potassium coordination polyhedra are irregular, with K1 and K3 six-coordinated and the third one $\mathrm{K} 2$ seven-coordinated. The $\mathrm{K}-\mathrm{O}$ distances range from $2.652(9)$ to $3.100(2) \AA$ (mean: $2.790 \AA$ ) whereas the $\mathrm{K}-\mathrm{N}$ distance is $3.025(3) \AA$. The water molecules W2 is disordered over three positions with occupancies of approximately 0.6, 0.2 and 0.2 . The hydrogen atom $(\mathrm{H} 1 \mathrm{~W} 1)$ of the ordered water molecule $(\mathrm{O} 1 \mathrm{~W})$ is hydrogen bonded to the sulfonyl oxygen atom $(\mathrm{O} 11)(R(\mathrm{O} \cdots \mathrm{O})=2.976(3) \AA)$, whereas the other hydrogen atom $(\mathrm{H} 2 \mathrm{~W} 1)$ is bifurcated to the carbonyl oxygen atom $(\mathrm{O} 13)(R(\mathrm{O} \cdots \mathrm{O})=2.851(3) \AA)$ and the disordered water molecules $(\mathrm{O} 23 \mathrm{~W})(R(\mathrm{O} \cdots \mathrm{O})=3.067(12) \AA)$. The carbonyl oxygens $(\mathrm{O} 13$, $\mathrm{O} 23$ and $\mathrm{O} 33)$ and one of the disordered water molecules $(\mathrm{O} 22 \mathrm{~W})$ are involved in $\mathrm{C}-\mathrm{H} \cdots \mathrm{O}$ hydrogen bonds $(R(\mathrm{C}-\mathrm{H} \cdots \mathrm{O})=3.027(4)-3.304(9) \AA)$. Structural characteristics of the studied compound are compared with the analogous trisodium trisaccharinate dihydrate and dipotassium sodium trisaccharinate monohydrate. Infrared and Raman spectra of the title compound have been analyzed in relation to the structure, and compared with the spectra of trisodium trisaccharinate dihydrate.

(c) Central European Science Journals. All rights reserved.
\end{abstract}

Keywords: Potassium saccharinate dihydrate; crystal structure; vibrational (infrared and Raman) spectra; structure-spectral correlations 


\section{Introduction}

Mainly due to the suspected carcinogenic nature ([1], [2]) of saccharin (systematic name: 1,2-benzisothiazole-3(2H)-one 1,1-dioxide; Figure 1), its use as a food additive, and the versatile coordination properties of its deprotonated form in its salts and complexes with various metals, extensive studies have been devoted to saccharinates during the last few decades. Among them, the alkali saccharinates have received the widest commercial use in the food industry, by reason of their high solubility in water compared to saccharin itself.

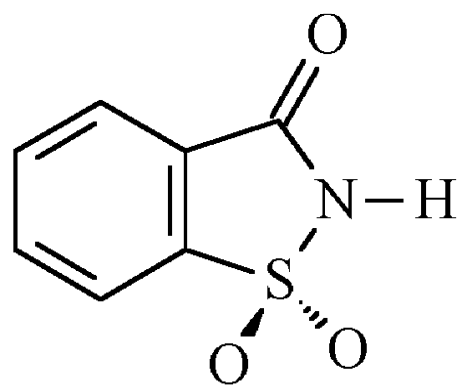

Fig. 1 Structural formula of saccharin.

In spite of that, reported structural and vibrational spectroscopic data on the alkali and pseudoalkali saccharinates are still rather scanty. Crystal structures of $\mathrm{Na}_{3}(\mathrm{sac})_{3} \cdot 2 \mathrm{H}_{2} \mathrm{O}$ [3], $\mathrm{K}_{2} \mathrm{Na}(\mathrm{sac})_{3} \cdot \mathrm{H}_{2} \mathrm{O}$ [4] and $\mathrm{NH}_{4}$ (sac) [5] have been reported ( $\mathrm{sac}=$ saccharinato anion). A tentative assignment of the room temperature (RT) infrared spectra of the saccharinates of $\mathrm{Na}$ and $\mathrm{K}$ has also been given [6] and a more detailed study of the $\mathrm{OH}$ and OD stretching vibrations in the infrared spectra of these two compounds has been reported [7]. The infrared spectrum of $\mathrm{Li}$ saccharinate in the region of the $\mathrm{CO}, \mathrm{SO}_{2}$ and water stretching vibrations has also been studied [8]. Recently, results of the vibrational (IR and Raman) study and spectra-structure correlations in ammonium saccharinate were published [9].

In order to obtain additional structural data concerning the ligation properties of saccharin in the salts with various alkali metals, we have undertaken a systematic and detailed structural and spectroscopic study of the alkali saccharinates. In the present comparative study, we report the results of structural and vibrational investigations of potassium saccharinate in comparison with the analogous sodium and mixed potassium sodium salts. Thereby, the complete assignment of the infrared and Raman spectra in the 1700-1100 $\mathrm{cm}^{-1}$ is performed, paying special attention to the $\mathrm{C}=\mathrm{O}$ and $\mathrm{SO}_{2}$ stretchings and their correlation with the structural data. The $\mathrm{O}-\mathrm{H}$ and $\mathrm{O}-\mathrm{D}$ stretching vibrations of the protiated and partially deuterated samples related to the presence of one ordered and one disordered water molecule in the structure are studied as well.

\footnotetext{
* E-mail: gligor@pmf.ukim.edu.mk

$\dagger$ E-mail: kaitner@chem.pmf.hr
} 


\section{Experimental}

\subsection{Preparation}

The crystals of tripotassium trisaccharinate dihydrate, $\mathrm{K}_{3}(\mathrm{sac})_{3} \cdot 2 \mathrm{H}_{2} \mathrm{O}$, were prepared from warm aqueous solution of saccharin and potassium carbonate. Recrystallization from aqueous and ethanolic solutions afforded an identical crystalline phase, with crystals suitable for X-ray diffraction. Deuterated analogues were obtained by recrystallization of the protiated sample from $\mathrm{D}_{2} \mathrm{O}$.

\section{$2.2 \quad$ FT-IR and Raman measurements}

The room temperature (RT) and liquid nitrogen temperature (LNT) FT-IR absorption spectra in the 4000-400 $\mathrm{cm}^{-1}$ range were recorded on a Perkin-Elmer System 2000 instrument (32 background and 64 sample spectra averaged at resolution of $4 \mathrm{~cm}^{-1}$ ). Since no differences were found between spectra recorded in paraffin oil and KBr pellets, the latter technique was employed. A Graseby Specac P/N 21525 variable-temperature cell with $\mathrm{KBr}$ windows was used for the low-temperature infrared measurements. The Raman spectrum was recorded on a Renishaw 2000 instrument equipped with a Leica microscope, using a $514 \mathrm{~nm}$ argon-ion or a $780 \mathrm{~nm}$ diode laser.

\subsection{Crystallographic measurements}

The colourless prismatic crystals with dimensions $0.80 \times 0.35 \times 0.35 \mathrm{~mm}$ were used for $\mathrm{X}$-ray data collection. The crystallographic measurements were performed by the $\omega$-scan method on a Philips PW1100 diffractometer using graphite monochromatized Mo- $K \alpha$ radiation. Details of the crystal data and refinement parameters for the studied compound $\mathrm{K}_{3}(\mathrm{sac})_{3} \cdot 2 \mathrm{H}_{2} \mathrm{O}(\mathbf{1})$ compared with the corresponding values for the analogous $\mathrm{Na}_{3}(\mathrm{sac})_{3}$. $2 \mathrm{H}_{2} \mathrm{O}(2)$ [3] and $\mathrm{K}_{2} \mathrm{Na}(\mathrm{sac})_{3} \cdot \mathrm{H}_{2} \mathrm{O}(3)$ [4] are presented in Table 1. The semi-empirical $\psi$-scan absorption correction was applied to the data set [10]. The structure was solved by direct methods and refined by full-matrix least-squares calculations with all non-hydrogen atoms allowed anisotropic motion. The saccharinato hydrogen atoms were positioned geometrically $0.95 \AA$ from the atom to which they were bonded and included (but not refined) in the final rounds of calculations. The hydrogen atoms (H1W1 and H2W1) belonging to the ordered water molecule (W1) were taken from the difference Fourier map and included as riding atoms in the structure factor calculations. The hydrogen atom positions of the disordered water molecule (W2) were not determined. Atomic scattering factors were taken from International Tables for X-ray Crystallography (1974) [11]. Computing was carried out on a personal computer using SHELXL97 integrated in WinGX [12], [13]. The ORTEP-III [14] and PLUTON [15] programs were used to generate the illustrations. 


\section{Results and discussion}

At first sight, the crystal data of the studied $\mathrm{K}_{3}(\mathrm{sac})_{3} \cdot 2 \mathrm{H}_{2} \mathrm{O}(\mathbf{1})$ differ from the previously published values of the analogous $\mathrm{Na}_{3}(\mathrm{sac})_{3} \cdot 2 \mathrm{H}_{2} \mathrm{O}^{\ddagger}(\mathbf{2})[3]$ as well as of the double potassium sodium salt with very similar formula $\mathrm{K}_{2} \mathrm{Na}(\mathrm{sac})_{3} \cdot \mathrm{H}_{2} \mathrm{O}(\mathbf{3})$ (see [4] and Table 1). However, transformation of the crystal data for compounds in (2) and (3) (using transformation matrix of type: 00 1; 0 -1 0; 100 - for the axes, and $\alpha($ new $)=180^{\circ}-\gamma($ old $)$; $\beta($ new $)=\beta($ old $) ; \gamma($ new $)=180^{\circ}-\gamma($ old $)$ - for the angles $)$ shows that, in addition to their crystallization into the same crystal system (triclinic) and space group $(P \underline{1})$, they have comparable unit cell parameters and consequently are isostructural with the studied compound (1).

\subsection{Crystal structure description}

The final atomic parameters as well as the complete list of data concerning bond lengths and angles are available in CIF format as Electronic Supplementary Information (CCDC reference number 218495). Comparison of the interatomic distances of the $\mathrm{K}^{+}$and $\mathrm{Na}^{+}$ ions for (1)-(3) is given in Table 2. Table 3 presents the selected bond lengths $(\AA)$ and angles $\left(^{\circ}\right)$ in the saccharinato anions of the studied compound $\mathrm{K}_{3}(\mathrm{sac})_{3} \cdot 2 \mathrm{H}_{2} \mathrm{O}$ compared with the corresponding values in the analogous $\mathrm{Na}_{3}(\mathrm{sac})_{3} \cdot 2 \mathrm{H}_{2} \mathrm{O}$ [3] and $\mathrm{K}_{2} \mathrm{Na}(\mathrm{sac})_{3} \cdot \mathrm{H}_{2} \mathrm{O}$ [4]. The hydrogen bonds of $\mathrm{K}_{3}(\mathrm{sac})_{3} \cdot 2 \mathrm{H}_{2} \mathrm{O}$ are listed in Table 4. The crystal structure packing is shown in Figure 2. The "surrounding" of the potassium cations is illustrated in Figure 3.

Similarly to the previously studied trisodium trisaccharinate dihydrate [3], the structure of the potassium compound (1) consists of three crystallographically independent potassium and saccharinato ions as well as two structurally different water molecules (Figure 2). One of the water molecules (W2) is disordered, the corresponding occupation factors being $0.66(3), 0.190(5)$ and $0.147(5)$ for O21W, O22W and O23W, respectively. Two of the $\mathrm{K}^{+}$cations are six-coordinated; $\mathrm{K} 1$ is surrounded by five saccharinato oxygens and one water oxygen atom, whereas K3 has as nearest neighbours four saccharinato oxygens, one saccharinato nitrogen atom and one water oxygen atom (Figure 3). The third $\mathrm{K}^{+}$cation $(\mathrm{K} 2)$ is seven-coordinated by five saccharinato oxygens and two water oxygen atoms (Figure 3). All coordination polyhedra are irregular. The $\mathrm{K}-\mathrm{O}$ distances range from $2.652(3)$ to $3.100(2) \AA($ mean value: $2.790 \AA$ ) whereas the K3-N distance is $3.025(3) \AA$. The shorter mean $\mathrm{K}-\mathrm{O}$ distance $(2.790 \AA)$ in $(\mathbf{1})$ compared to the mean $\mathrm{K}-\mathrm{O}$ value $(2.818 \AA)$ in $(\mathbf{3})$ suggests stronger interaction between the $\mathrm{K}^{+}$cations and saccharinato anions in the compound (1) (Table 2). This observation is not supported by the comparison of the unique $\mathrm{K}-\mathrm{N}$ distance in (1) (3.025 $\AA$ ) with the corresponding mean

$¥$ Recrystallization of the commercially available sodium saccharinate from water and ethanol yields two different forms: The crystals recrystallized from ethanol are triclinic with formula $\mathrm{Na}_{3}(\mathrm{sac})_{3} \cdot 2 \mathrm{H}_{2} \mathrm{O}$ [3] , whereas the crystals obtained from aqueous solution are monoclinic. The composition of the latter has not been determined with certainty yet, but it has been assured that the compound is a higher hydrate [7] than that obtained from ethanol. 
$\mathrm{K}-\mathrm{N}$ distance in $(\mathbf{3})(3.001 \AA)$. As seen from Table 2 , the delta value 0.372 obtained by subtraction of the mean $\mathrm{Na}-\mathrm{N}$ distance $(2.635 \AA)$ in $(\mathbf{2})$ and $(\mathbf{3})$ from the mean $\mathrm{K}-\mathrm{N}$ distance $(3.007 \AA)$ in $(\mathbf{1})$ and $(\mathbf{3})$ corresponds very closely to the delta value 0.36 obtained by subtraction of the $r\left(\mathrm{Na}^{+}\right)=1.02 \AA$ (for $\mathrm{CN}=6$ ) from the $r\left(\mathrm{~K}^{+}\right)=1.38 \AA$ (for $\mathrm{CN}=6$ ) [16]. The corresponding delta value obtained by subtraction of the mean $\mathrm{Na}-\mathrm{O}$ distance $(2.469 \AA)$ in $(\mathbf{2})$ and $(\mathbf{3})$ from the mean $\mathrm{K}-\mathrm{O}$ distance $(2.780 \AA)$ in $(\mathbf{1})$ and $(\mathbf{3})$ is smaller (0.311), but still close to $r\left(\mathrm{~K}^{+}\right)-r\left(\mathrm{Na}^{+}\right)=0.372$.

There are no significant differences between the interatomic distances and angles in the crystallographically different saccharinato anions of the studied compound (Table 3). Comparison also shows that the corresponding interatomic distances and angles in the five-membered rings of the deprotonated saccharins in compounds (1), (2) and (3) are very closely similar.

The carbonyl and sulfonyl saccharinato oxygen atoms are involved in hydrogen bonds with the water molecules and with some of the saccharinato $\mathrm{C}-\mathrm{H}$ groups. In particular, the hydrogen atom H1W1 belonging to the water molecule $\mathrm{O} 1 \mathrm{~W}$ is hydrogen bonded to the sulfonyl saccharinato oxygen atom $\mathrm{O} 11(R(\mathrm{O} \cdots \mathrm{O})=2.976(3) \AA)$, whereas the other hydrogen atom $\mathrm{H} 2 \mathrm{~W} 1$ is bifurcated to the carbonyl saccharinato oxygen atom $\mathrm{O} 13$ $(R(\mathrm{O} \cdots \mathrm{O})=2.851(3) \AA)$ and to $\mathrm{O} 2 \mathrm{~W}$ oxygen atom belonging to water molecule with population parameter $0.147(5)$ (the position $\mathrm{O} 23 \mathrm{~W})(R(\mathrm{O} \cdots \mathrm{O})=3.067(12) \AA)$. The carbonyl saccharinato oxygen atoms (O13, O23 and O33) and the $\mathrm{O} 2 \mathrm{~W}$ oxygen atom belonging to water molecule with population parameter 0.190(5) (the position $\mathrm{O} 22 \mathrm{~W}$ ) are involved in $\mathrm{C}-\mathrm{H} \cdots \mathrm{O}$ hydrogen bonds $(R(\mathrm{C}-\mathrm{H} \cdots \mathrm{O})=3.027(4)-3.304(9) \AA)($ Table 4$)$.

\subsection{Vibrational studies}

\subsubsection{General considerations}

Contrary to the existence of two different hydrates of sodium saccharinate (triclinic from ethanol and monoclinic from aqueous solution [3], [7]), the IR spectra and the powder diffractograms showed that identical hydrate of potassium saccharinate is obtained both from water and ethanol. The XRD and thermal data [17] confirmed that the potassium compound (1) corresponds to the triclinic form of trisodium trisaccharinate dihydrate, $\mathrm{Na}_{3}(\mathrm{sac})_{3} \cdot 2 \mathrm{H}_{2} \mathrm{O}(2)$ [3], having the analogous formula, $\mathrm{K}_{3}(\mathrm{sac})_{3} \cdot 2 \mathrm{H}_{2} \mathrm{O}$. Although their room temperature (RT) IR spectra are very similar, significant differences exist between the $\mathrm{O}-\mathrm{H}$ and $\mathrm{O}-\mathrm{D}$ stretching region of the infrared spectra of (1), on the one hand, and (2), on the other hand, recorded at the nitrogen boiling temperature (LNT) [7]. This was taken as a serious indication that, in spite of the fact that these two compounds are isostructural, significant differences exist in the structural arrangement of the water molecules. This presumption has been now confirmed by the crystal structure determination of (1).

The assignment of the experimental frequencies in the RT and LNT IR and RT Raman spectra of tripotassium trisaccharinate dihydrate is given in Table 5. This assignment is based on theoretical calculations on deprotonated saccharin (saccharinate anion) in the 
$1700-1000 \mathrm{~cm}^{-1}$ region. Some of the characteristic saccharinate vibrations, such as the $\mathrm{C}=\mathrm{O}$ and $\mathrm{SO}_{2}$ stretches belonging to the five-membered ring as well as the $\mathrm{O}-\mathrm{H}$ and $\mathrm{O}-\mathrm{D}$ stretches of the water molecules will be discussed here. The number of bands arising from these vibrations, and their frequencies, will be correlated with the crystallographic values of the corresponding interatomic distances.

\subsubsection{The $\mathrm{O}-\mathrm{H}$ and $\mathrm{O}-\mathrm{D}$ stretches}

The $\mathrm{O}-\mathrm{H}$ stretching region of protiated $(\mathbf{1})$ and the $\mathrm{O}-\mathrm{D}$ stretching region of its partially deuterated analogue are shown in figures 3 and 4, respectively. In the region of the $\mathrm{O}-\mathrm{H}$ stretches, two strong and complex RT bands with maxima at 3557 and $3397 \mathrm{~cm}^{-1}$ are accompanied by a shoulder around $3258 \mathrm{~cm}^{-1}$ (Figure 4a). Sharpening, splittings and shifts of the bands are observed with decrease of the temperature, resulting in at least seven overlapped bands with frequencies ranging from 3585 down to $3254 \mathrm{~cm}^{-1}$ (Figure $4 \mathrm{~b})$. The band positions are consistent with the existence of non-hydrogen bonded and weakly to medium hydrogen bonded water molecules in the structure (see Table 4).

Because the extensive vibrational interactions preclude direct comparison of the number of bands in the $\mathrm{O}-\mathrm{H}$ stretching region of protiated sample with the geometry of the water molecules, the LNT spectrum of the isotopically isolated HOD molecules in the partially deuterated (1) was studied. The data obtained can assist in correlating the spectrum with the hydrogen bonding. As seen from Figure 5, three intense and well separated bands $\left(2615,2548\right.$ and $\left.2471 \mathrm{~cm}^{-1}\right)$ appear in the IR spectrum, the lowestfrequency one being the most intense. The three main bands are accompanied by at least four to five less intense bands or shoulders (2634, 2596, 2507, 2484 and $2416 \mathrm{~cm}^{-1}$ ). At least qualitatively, the total number of eight registered bands with variable intensity in the $\nu(\mathrm{OD})$ region of the partially deuterated sample corresponds with the presence of one ordered (W1) and one triply-disordered water molecule (W2) with the approximate occupation factors 0.6, 0.2 and 0.2. The three most intense bands (the one at 2471 $\mathrm{cm}^{-1}$ being considerably stronger than the other two) could be related to the four O-D stretching vibrations arising from the ordered water molecule W1 and the disordered water molecule W2 with occupancy 0.6. The other less intense bands or shoulders probably appear as a result of $\nu(\mathrm{OD})$ vibrations of the two disordered water positions of W2, each with approximate occupancy of 0.2 .

\subsubsection{The $\mathrm{C}=\mathrm{O}$ stretches}

As has been shown by theoretical calculations ([9], [18]), and confirmed experimentally [9, 18-21] (see also Table 5), the stretching vibrations of the carbonyl and the sulfonyl groups can be considered as characteristic group vibrations, manifested as very strong bands in the vibrational (infrared and Raman) spectra of the corresponding compounds. Therefore they are often used to correlate the spectroscopic data with those obtained by structure determination.

The analysis of the bands originating from the $\mathrm{C}=\mathrm{O}$ stretch mode in the infrared spectra of various metal saccharinates is complicated by the appearance, in the same 
spectral region, of bands arising from the benzenoid ring stretches as well as from the water bending modes. According to ab initio calculations for deprotonated saccharin [18], the benzenoid stretching bands appear at somewhat lower frequencies (below $1610 \mathrm{~cm}^{-1}$ ) and are sharper and less intense than the bands originating from the $\mathrm{C}=\mathrm{O}$ stretches. Recording the spectra of samples with high deuterium content, however, eliminates the bands due to the $\mathrm{H}-\mathrm{O}-\mathrm{H}$ bending vibrations from the region where the $\nu(\mathrm{CO})$ modes are expected.

As indicated in Figure 6, a pair of bands appears in the RT IR spectrum (1650 and $1641 \mathrm{~cm}^{-1}$ ) and also in the Raman spectrum (1647 and $1636 \mathrm{~cm}^{-1}$ ) (see also Table 5) of the studied compound in the region where $\nu(\mathrm{CO})$ stretching mode is expected. Five bands (two well separated and three shoulders), however, are registered in this spectral region of the IR spectrum of the same compound recorded at LNT (see Figures 6 and 8 and Table 5 ). The reduced intensity of the bands at 1665,1643 and $1637 \mathrm{~cm}^{-1}$ in the LNT spectrum of the deuterated analogue ( $c a .30 \%$ deuterium content) in comparison with the protiated one (Figure 8) confirms that they belong to the $\delta(\mathrm{HOH})$ modes. In addition to the strongest band at $1651 \mathrm{~cm}^{-1}$, exception is the shoulder at $1626 \mathrm{~cm}^{-1}$ in the IR spectrum of the protiated sample which in the spectrum of the deuterated analogue separates as a sharp band. On the basis of these considerations, the uninfluenced by deutertion strongest single band at $1651 \mathrm{~cm}^{-1}$ could be attributed to the $\nu(\mathrm{CO})$ modes. It corresponds with presence of three crystallographically different saccharinato $\mathrm{CO}$ groups in the structure of the studied compound with very short $\mathrm{C}-\mathrm{O}$ distances $(1.234(3), 1.236(3)$ and 1.239(3) $\AA$ ). However, the origin of the second uninfluenced by deutertion weaker LNT band at $1626 \mathrm{~cm}^{-1}$ ) remains still unclear, although most probably its origin is other than the $\nu(\mathrm{CO})$ mode.

\subsubsection{The $\mathrm{SO}_{2}$ stretches}

Similarly to the $\mathrm{C}=\mathrm{O}$ stretches, the assignment of the bands originating from the $\mathrm{SO}_{2}$ (sulfonyl) stretching vibrations in the spectra of saccharinato salts and complexes is usually complicated by the appearance of additional bands originating from ring vibrations of the saccharinato ions (ligands) [22-24]. The bands arising from the benzenoid stretches, however, are found to be sharper and less intense than the sulfonyl stretching bands and thus the strongest bands in the $1300-1150 \mathrm{~cm}^{-1}$ spectral region are usually attributed to the antisymmetric and symmetric $\nu\left(\mathrm{SO}_{2}\right)$ modes. A detailed analysis of infrared spectra of metal saccharinates in the $\mathrm{SO}_{2}$ stretching region has shown that the $\nu\left(\mathrm{SO}_{2}\right)$ frequency depends on the $\mathrm{O}-\mathrm{S}-\mathrm{O}$ angles rather than on the $\mathrm{S}-\mathrm{O}$ distances [19].

Two strong bands are registered in the RT infrared spectrum of the studied compound in the region where the $\nu\left(\mathrm{SO}_{2}\right)$ modes are expected (Figure 6$)$. There is no doubt that the band at $1255 \mathrm{~cm}^{-1}$ can be assigned as the $\nu_{\text {as }}\left(\mathrm{SO}_{2}\right)$ mode, whereas the band at $1150 \mathrm{~cm}^{-1}$ can be attributed to the $\nu_{s}\left(\mathrm{SO}_{2}\right)$ mode (Table 5). As expected, the band corresponding to the antisymmetric stretching $\mathrm{SO}_{2}$ mode in the Raman spectrum is of a weak intensity (at $1257 \mathrm{~cm}^{-1}$ ) compared to the strong band arising from the symmetric $\mathrm{SO}_{2}$ mode (at $1151 \mathrm{~cm}^{-1}$ ) (Figure 7 and Table 5). The Raman frequencies of these two modes are 
practically the same as those found in the RT infrared spectrum. The appearance of only one pair of RT infrared and Raman $\nu\left(\mathrm{SO}_{2}\right)$ bands, in contrast to the existence of three crystallographic types of sulfonyl groups in the studied compound, is due to the similarity between the interatomic distances and especially the $\mathrm{O}-\mathrm{S}-\mathrm{O}$ angles in the different $\mathrm{SO}_{2}$ groups (Table 3). The presence, however, of three crystallographically different types of $\mathrm{SO}_{2}$ groups in the structure of the studied compound could be the reason for splitting of the $\nu\left(\mathrm{SO}_{2}\right)$ bands into two components and, consequently, appearance of two pairs of $\mathrm{SO}_{2}$ stretching bands in its LNT infrared spectrum (Figure 6 and Table 5).

\section{Conclusion}

The study of the crystal structure and the vibrational (infrared and Raman) spectra has shown that, by contrast with the previously confirmed existence of two different hydrates of sodium saccharinate (triclinic from ethanol and monoclinic from water), identical crystal phases of potassium saccharinate are obtained by its recrystallization from aqueous and ethanolic solutions. Although at first sight the crystal data for $\mathrm{K}_{3}(\mathrm{sac})_{3} \cdot 2 \mathrm{H}_{2} \mathrm{O}$ (1) differ from the published values for the analogous triclinic $\mathrm{Na}_{3}(\mathrm{sac})_{3} \cdot 2 \mathrm{H}_{2} \mathrm{O}(\mathbf{2})$ [3] and $\mathrm{K}_{2} \mathrm{Na}(\mathrm{sac})_{3} \cdot \mathrm{H}_{2} \mathrm{O}(\mathbf{3})$ [4], the more detailed analysis has shown that compounds (1), (2) and (3) have comparable unit cell parameters. In spite of that, one of the water molecules (W2) in the studied potassium compound (1) was found to be triply-disordered, the corresponding occupation factors being $0.66(3), 0.190(5)$ and $0.147(5)$ for $\mathrm{O} 21 \mathrm{~W}, \mathrm{O} 22 \mathrm{~W}$ and $\mathrm{O} 23 \mathrm{~W}$, respectively. This has been confirmed, at least qualitatively, by analysis of the infrared spectrum of partially deuterated $\mathrm{K}_{3}(\mathrm{sac})_{3} \cdot 2 \mathrm{H}_{2} \mathrm{O}$ in the $\mathrm{O}-\mathrm{D}$ stretching region.

Despite the presence of three crystallographically different saccharinato ions in the structure of $\mathrm{K}_{3}(\mathrm{sac})_{3} \cdot 2 \mathrm{H}_{2} \mathrm{O}$, the corresponding interatomic $\mathrm{C}-\mathrm{O}$ and $\mathrm{S}-\mathrm{O}$ distances and especially the $\mathrm{O}-\mathrm{S}-\mathrm{O}$ angles in the $\mathrm{CO}$ and $\mathrm{SO}_{2}$ groups are very similar. Accordingly, a single band in the region where the $\nu(\mathrm{CO})$ are expected as well as only one pair of infrared and Raman $\nu(\mathrm{CO})$ bands in the $\mathrm{SO}_{2}$ stretching region are observed.

\section{Acknowledgment}

The financial support of the Ministry of Education and Science of the Republic of Macedonia and the Ministry of Science and Technology of the Republic of Croatia are gratefully acknowledged.

\section{References}

[1] J.M. Price, C.G. Biava, B.L. Oser, E.E. Vogin, J. Steinfeld and H.L. Ley: "Bladder Tumors in Rats Fed Cyclohexylamine or High Doses of a Mixture of Cyclamate and Saccharin“, Science, Vol. 167, (1970), pp. 1131-1132.

[2] N. Suzuki, H. Suzuki: "Suppression of Saccharin-induced Mutagenicity by Interferon$\alpha$ in Human RSa Cells", Cancer Res., Vol. 55, (1995), pp. 4253-4256. 
[3] G. Jovanovski, B. Kamenar: "Two Ionic Saccharinates: (1a) Sodium Saccharinate $2 / 3$ Hydrate, $\mathrm{C}_{7} \mathrm{H}_{4} \mathrm{NO}_{3} \mathrm{SNa} \cdot 2 / 3 \mathrm{H}_{2} \mathrm{O}$; (1b) Magnesium Disaccharinate Heptahydrate, $\left(\mathrm{C}_{7} \mathrm{H}_{4} \mathrm{NO}_{3} \mathrm{~S}\right)_{2} \mathrm{Mg} \cdot 7 \mathrm{H}_{2} \mathrm{O}$ ", Cryst. Struct. Commun., Vol. 11, (1982), pp. 247-255.

[4] K.M.A. Malik, S.Z. Haider and M.A. Hossain: "Dipotassium Sodium Trisaccharinate

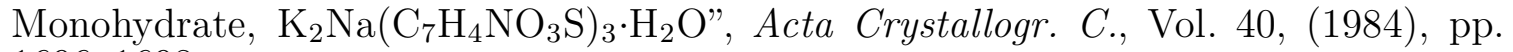
1696-1698.

[5] S.W. Ng, "Ammonium Saccharin", Acta Crystallogr. C., Vol. 54, (1998), pp. 649-651.

[6] S. Natarajan, G. Subramanian: "Infra-red Spectra of Sodium and Potassium Saccharinates", Indian J. Phys. B., Vol. 60, (1986), pp. 470-473.

[7] G. Jovanovski, O. Grupce and B. Soptrajanov,: "The O-H and O-D Stretching Vibrations in the Hydrates of Sodium and Potassium Saccharinate: Spectra-structure Correlations", J. Mol. Struct., Vol. 219, (1990), pp. 61-66.

[8] S. Tanceva: "Infrared Spectra of Li, Ag, $\mathrm{Sr}$ and $\mathrm{Pb}$ Saccharinates", MSc Thesis (in Macedonian); "Sv. Kiril i Metodij" University, Faculty of Science, Institute of Chemistry, Skopje, 1994.

[9] P. Naumov, G. Jovanovski: "Vibrational Study and Spectra-structure Correlations in Ammonium Saccharinate: Comparison with the Alkali Saccharinates", Spectrochim. Acta A., Vol. 56, (2000), pp. 1305-1318.

[10] A.C.T. North, D.C. Philips and F.S. Mathews: "A Semi-empirical Method of Absorption Correction", Acta Crystallogr. A., Vol. 24, (1968), pp. 351-359.

[11] International Tables for X-ray Crystallography, Vol. IV, Kynoch Press, Birmingham, 1974, pp. 99-101, 149-150. (Present Distributor Kluwer Academic Publishers, Dordrecht).

[12] G.M. Sheldrick: "SHELXL97. Release 97-1. Program for the Refinement of Crystal Structures“, University of Göttingen, Germany, 1997.

[13] L.J. Farrugia: "WinGX Suite for Small-molecule Single-crystal Crystallography", J. Appl. Crystallogr., Vol. 32, (1999), pp. 837-838.

[14] M.N. Burnett, C.K. Johnson: ORTEP-III, Report ORNL-6895., Oak Ridge National Laboratory, Oak Ridge, Tennessee 37831-6285, USA, 1996.

[15] A.I. Spek: PLUTON-93. Program for the Display and Analysis of Crystal and Molecular Structures, University of Utrecht, The Netherlands,1993.

[16] R.D. Shannon: "Revised Effective Ionic Radii and Systematic Studies of Interatomic Distances in Halides and Chalcogenides", Acta Crystallogr. A., Vol. 32, (1976), pp. $751-767$.

[17] P. Naumov, G. Jovanovski, S. Abbrent and L.-E. Tergenius: "Thermal Behavior of the Saccharinates of $\mathrm{K}^{+}, \mathrm{Na}^{+}, \mathrm{Rb}^{+}, \mathrm{Cs}^{+}$and $\mathrm{NH}_{4}^{+}$: Structural Inferences", Thermochim. Acta, Vol. 359, (2000), pp. 123-130.

[18] I.G. Binev, B. Stamboliyska and E. Velcheva: "The Infrared Spectra and Structure of $o$-sulfobenzimide (Saccharin) and of its Nitranion: An ab initio Force Field Treatment", Spectrochim. Acta A., Vol. 52, (1996), pp. 1135-1143.

[19] G. Jovanovski: "Metal Saccharinates and Their Complexes with N-donor Ligands", Croat. Chem. Acta, Vol. 73, (2000), pp. 843-868.

[20] G. Jovanovski, P. Naumov, O. Grupce and B. Kaitner: "Structural Study of Monoaquabis(pyridine)bis(saccharinato)copper(II), $\left[\mathrm{Cu}\left(\mathrm{H}_{2} \mathrm{O}\right)(\mathrm{py})_{2}(\mathrm{sac})_{2}\right]^{\prime \prime}$, Eur. J. Solid State Inorg. Chem., Vol. 35, (1998), pp. 231-242. 
[21] P. Naumov, O. Grupce and G. Jovanovski: "Experimental and Theoretical Raman Study of the Binuclear Copper(II) Imidazole Saccharinato Complex", J. Raman Spectrosc., Vol. 31, (2000), pp. 475-479.

[22] O. Grupce, G. Jovanovski and V. Mirceski: "Spectra-structure Correlations in 2,2'bipyridine Mercury(II) Saccharinate: Comparison with Mercury(II) Saccharinate and Chloromercury(II) Saccharinate", Spectrosc. Lett. Vol. 27, (1994), pp. 691-699.

[23] I. Hase: "The Infrared and Raman Spectra of Phthalimide, N- $d$-Phthalimide and Potassium Phthalimide", J. Mol. Struct., Vol. 48, (1978), pp. 33-42.

[24] I. Hase: "The Infrared and Raman Spectra of Tetrachlorophthalic Anhydride, Tetrachlorophthalimide, N- $d$ - Tetrachlorophthalimide and Potassium Tetrachlorophthalimide", J. Mol. Struct., Vol. 52, (1979), pp. 163-173. 


\begin{tabular}{|c|c|c|c|}
\hline & $\begin{array}{c}\mathrm{K}_{3}(\mathrm{sac})_{3} \cdot 2 \mathrm{H}_{2} \mathrm{O} \\
\mathbf{1} \\
(\text { this work) }\end{array}$ & $\begin{array}{c}\mathrm{Na}_{3}(\mathrm{sac})_{3} \cdot 2 \mathrm{H}_{2} \mathrm{O}[3] \\
\mathbf{2}\end{array}$ & $\begin{array}{c}\mathrm{K}_{2} \mathrm{Na}(\mathrm{sac})_{3} \cdot \mathrm{H}_{2} \mathrm{O}[4] \\
\mathbf{3}\end{array}$ \\
\hline Empirical formula & $\begin{array}{c}\mathrm{C}_{21} \mathrm{H}_{12} \mathrm{~N}_{3} \mathrm{O}_{9} \mathrm{~S}_{3} \mathrm{~K}_{3} . \\
\cdot 2 \mathrm{H}_{2} \mathrm{O}\end{array}$ & $\begin{array}{c}\mathrm{C}_{21} \mathrm{H}_{12} \mathrm{~N}_{3} \mathrm{O}_{9} \mathrm{~S}_{3} \mathrm{Na}_{3} \cdot \\
\cdot 2 \mathrm{H}_{2} \mathrm{O}\end{array}$ & $\begin{array}{c}\mathrm{C}_{21} \mathrm{H}_{12} \mathrm{~N}_{3} \mathrm{O}_{9} \mathrm{~S}_{3} \mathrm{~K}_{2} \mathrm{Na} \cdot \\
\cdot \mathrm{H}_{2} \mathrm{O}\end{array}$ \\
\hline Formula weight & 699.85 & 651.54 & 665.74 \\
\hline Temperature/K & 293 & 293 & 294 \\
\hline Crystal System & Triclinic & Triclinic & Triclinic \\
\hline Space group & $P \overline{1}$ & $P \overline{1}$ & $P \overline{1}$ \\
\hline$a / \AA$ & $7.619(1)$ & $15.237(8)[7.346(3)]^{*}$ & $16.428(5)[6.954(1)]^{*}$ \\
\hline$b / \AA$ & $12.325(1)$ & $11.640(5)[11.640(5)]$ & $12.122(4)[12.122(4)]$ \\
\hline$c / \AA$ & $15.521(1)$ & $7.346(3)[15.237(8)]$ & $6.954(1)[16.428(5)]$ \\
\hline$\alpha /^{o}$ & $72.29(1)$ & $96.31(3)[72.45(3)]$ & $97.61(2)[69.91(2)]$ \\
\hline$\beta /{ }^{o}$ & $86.58(1)$ & $87.64(3)[87.64(3)]$ & $77.36(2)[77.36(2)]$ \\
\hline$\gamma /{ }^{o}$ & $81.27(1)$ & $107.55(3)[83.69(3)]$ & $110.09(2)[82.39(2)]$ \\
\hline$V / \AA^{3}$ & $1372.2(2)$ & 1234.7 & 1266.5 \\
\hline$Z$ & 2 & 2 & 2 \\
\hline$\mu\left(M_{0} K \alpha\right) / \mathrm{cm}^{-1}$ & 7.89 & 4.22 & 6.3 \\
\hline$\theta$ range $/^{\circ}$ & $2.5-27$ & $2-30$ & \\
\hline Refflection collected & 6200 & 6641 & 5647 \\
\hline $\begin{array}{l}\text { Independent } \\
\text { reflections } R_{\text {int }}\end{array}$ & $5978 / 0.0127$ & 5365 & 4724 \\
\hline Goodness-of-fit $\left(F^{2}\right)$ & 1.057 & & \\
\hline $\begin{array}{l}\text { Final } R_{1} / \mathrm{w} R_{2} \\
\text { indices }\left(I>2 \sigma_{I}\right) \\
\qquad\left(I>3 \sigma_{I}\right)\end{array}$ & $0.0389 / 0.1252$ & 0.039 & $0.054 / 0.075$ \\
\hline
\end{tabular}

* Data given in squared brackets correspond to the transformed original data using the transformation matrix of type:

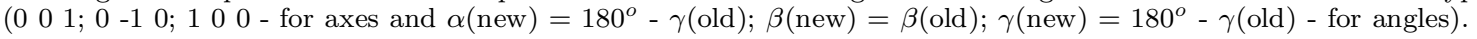

Table 1 Crystal data and structure refinement for $\mathrm{K}_{3}(\mathrm{sac})_{3} \cdot 2 \mathrm{H}_{2} \mathrm{O}$, and the respective data for $\mathrm{Na}_{3}(\mathrm{sac})_{3} \cdot 2 \mathrm{H}_{2} \mathrm{O}[3]$ and $\mathrm{K}_{2} \mathrm{Na}(\mathrm{sac})_{3} \cdot \mathrm{H}_{2} \mathrm{O}$ [4]. 

$\mathrm{K}_{3}(\mathrm{sac})_{3} \cdot 2 \mathrm{H}_{2} \mathrm{O}$
$\mathrm{Na}_{3}(\mathrm{sac})_{3} \cdot 2 \mathrm{H}_{2} \mathrm{O}[3]$
$\mathrm{K}_{2} \mathrm{Na}(\mathrm{sac})_{3} \cdot \mathrm{H}_{2} \mathrm{O}[4]$

(This work)

1

2

3

\begin{tabular}{|c|c|c|c|c|c|}
\hline $\mathrm{K} 1: \mathrm{CN}=6$ & & $\mathrm{Na} 1: \mathrm{CN}=6$ & & $\mathrm{Na} 1: \mathrm{CN}=6$ & \\
\hline $\mathrm{K} 1-\mathrm{O} 13$ & $2.735(2)$ & $\mathrm{Na}(1)-\mathrm{Ow}(1)$ & $2.344(2)$ & $\mathrm{Na}(1)-\mathrm{O}(13)^{i v}$ & $2.295(4)$ \\
\hline $\mathrm{K} 1-\mathrm{O} 21^{i}$ & $2.707(2)$ & $\mathrm{Na}(1)-\mathrm{Ow}(2)$ & $2.345(2)$ & $\mathrm{Na}(1)-\mathrm{O}(21)^{v}$ & $2.353(4)$ \\
\hline $\mathrm{K} 1-\mathrm{O} 31^{i i}$ & $72.878(2)$ & $\mathrm{Na}(1)-\mathrm{O}(32)$ & $2.580(2)$ & $\mathrm{Na}(1)-\mathrm{O}(1)^{v i}$ & $2.412(4)$ \\
\hline $\mathrm{K} 1-\mathrm{O} 31^{i i i}$ & $2.855(2)$ & $\mathrm{Na}(1)-\mathrm{O}(11)$ & $2.674(2)$ & $\mathrm{Na}(1)-\mathrm{O}(12)^{v}$ & $2.290(4)$ \\
\hline $\mathrm{K} 1-\mathrm{O} 32^{i v}$ & $2.741(2)$ & $\mathrm{Na}(1)-\mathrm{O}(12)$ & $2.602(2)$ & $\mathrm{Na}(1)-\mathrm{O}(1)^{v}$ & $2.841(4)$ \\
\hline $\mathrm{K} 1-\mathrm{O} 1 \mathrm{~W}^{i}$ & $2.797(2)$ & $\mathrm{Na}(1)-\mathrm{O}(13)^{i}$ & $2.365(2)$ & $\mathrm{Na}(1)-\mathrm{N}(31)^{v i}$ & $2.538(4)$ \\
\hline $\mathrm{K} 2: \mathrm{CN}=7$ & & $\mathrm{Na} 2: \mathrm{CN}=6$ & & $\mathrm{~K} 1: \mathrm{CN}=8$ & \\
\hline $\mathrm{K} 2-\mathrm{O} 12^{i i i}$ & $2.808(2)$ & $\mathrm{Na}(2)-\mathrm{Ow}(2)^{i i}$ & $2.400(2)$ & $\mathrm{K}(1)-\mathrm{O}(12)$ & $2.749(3)$ \\
\hline $\mathrm{K} 2-\mathrm{O} 21^{i i i}$ & $2.780(2)$ & $\mathrm{Na}(2)-\mathrm{O}(21)^{i}$ & $2.431(2)$ & $\mathrm{K}(1)-\mathrm{O}(23)^{i}$ & $3.113(4)$ \\
\hline $\mathrm{K} 2-\mathrm{O} 22^{i i i}$ & $3.070(2)$ & $\mathrm{Na}(2)-\mathrm{O}(22)$ & $2.796(2)$ & $\mathrm{K}(1)-\mathrm{O}(1)^{i i i}$ & $2.928(4)$ \\
\hline $\mathrm{K} 2-\mathrm{O} 23^{i v}$ & $2.705(2)$ & $\mathrm{Na}(2)-\mathrm{O}(22)^{i i}$ & $2.527(2)$ & $\mathrm{K}(1)-\mathrm{O}(32)^{i i i}$ & $2.959(3)$ \\
\hline $\mathrm{K} 2-\mathrm{O} 31^{i}$ & $3.100(2)$ & $\mathrm{Na}(2)-\mathrm{O}(33)^{i i i}$ & $2.349(2)$ & $\mathrm{K}(1)-\mathrm{O}(22)^{i}$ & $2.865(3)$ \\
\hline $\mathrm{K} 2-\mathrm{O} 1 \mathrm{~W}^{i i i}$ & $2.776(2)$ & $\mathrm{Na}(2)-\mathrm{O}(12)^{i i}$ & $2.430(2)$ & $\mathrm{K}(1)-\mathrm{N}(11)^{i i}$ & $2.889(4)$ \\
\hline $\mathrm{K} 2-\mathrm{O} 21 \mathrm{~W}^{*}$ & $2.702(3)$ & & & $\mathrm{K}(1)-\mathrm{O}(31)^{i i}$ & $2.817(3)$ \\
\hline $\mathrm{K} 2-\mathrm{O} 23 \mathrm{~W}^{*}$ & $2.652(9)$ & & & $\mathrm{K}(1)-\mathrm{N}(31)^{i i i}$ & $3.236(6)$ \\
\hline $\mathrm{K} 3: \mathrm{CN}=6$ & & $\mathrm{Na} 3: \mathrm{CN}=6$ & & $\mathrm{~K} 2: \mathrm{CN}=6$ & \\
\hline $\mathrm{K} 3-\mathrm{O} 11^{v}$ & $2.891(2)$ & $\mathrm{Na}(3)-\mathrm{Ow}(1)^{i i i}$ & $2.331(2)$ & $\mathrm{K}(2)-\mathrm{O}(11)$ & $2.728(4)$ \\
\hline $\mathrm{K} 3-\mathrm{O} 12^{v i}$ & $2.821(2)$ & $\mathrm{Na}(3)-\mathrm{N}(3)$ & $2.731(3)$ & $\mathrm{K}(2)-\mathrm{O}(31)$ & $2.802(3)$ \\
\hline $\mathrm{K} 3-\mathrm{N} 1^{v}$ & $3.025(3)$ & $\mathrm{Na}(3)-\mathrm{O}(31)$ & $2.681(2)$ & $\mathrm{K}(2)-\mathrm{O}(23)^{v}$ & $2.654(4)$ \\
\hline $\mathrm{K} 3-\mathrm{O} 33^{v i i}$ & $2.767(2)$ & $\mathrm{Na}(3)-\mathrm{O}(32)^{i i i}$ & $2.534(2)$ & $\mathrm{K}(2)-\mathrm{N}(21)$ & $2.878(4)$ \\
\hline $\mathrm{K} 3-\mathrm{O} 33^{i v}$ & $2.654(2)$ & $\mathrm{Na}(3)-\mathrm{O}(23)$ & $2.304(2)$ & $\mathrm{K}(2)-\mathrm{O}(22)^{i v}$ & $2.786(3)$ \\
\hline $\mathrm{K} 3-\mathrm{O} 21 \mathrm{~W}^{i v *}$ & $2.704(3)$ & $\mathrm{Na}(3)-\mathrm{O}(23)^{i v}$ & $2.437(2)$ & $\mathrm{K}(2)-\mathrm{O}(11)^{i v}$ & $2.599(4)$ \\
\hline $\mathrm{K} 3-\mathrm{O} 22 \mathrm{~W}^{i v *}$ & $2.711(8)$ & & & & \\
\hline $\mathrm{K} 3-\mathrm{O} 23 \mathrm{~W}^{i v *}$ & $2.726(9)$ & & & & \\
\hline$(\mathrm{K}-\mathrm{O})_{\text {mean }}$ & 2.790 & & & $(\mathrm{~K}-\mathrm{O})_{\text {mean }}$ & 2.818 \\
\hline \multirow[t]{3}{*}{$(\mathrm{K}-\mathrm{N})_{\text {mean }}$} & 3.025 & & & $(\mathrm{~K}-\mathrm{N})_{\text {mean }}$ & 3.001 \\
\hline & & $(\mathrm{Na}-\mathrm{O})_{\text {mean }}$ & 2.478 & $(\mathrm{Na}-\mathrm{O})_{\text {mean }}$ & 2.438 \\
\hline & & $(\mathrm{Na}-\mathrm{N})_{\text {mean }}$ & 2.731 & $(\mathrm{Na}-\mathrm{N})_{\text {mean }}$ & 2.538 \\
\hline
\end{tabular}

${ }^{a}$ Symmetry transformations used to generate equivalent atoms: (none) $x, y, z ;(i) x,-1+y, z ;(i i) \quad x,-1+y, 1+z ;(i i i)$ $-x, 1-y, 1-z ;($ iv) $1-x, 1-y, 1-z ;(v) 1-x, 1-y, 2-z ;(v i) 1+x, y, z ;(v i i) x, y, 1+z$.

${ }^{b}$ Symmetry transformations taken from references 3 and 4 , respectively.

* Disordered water molecule with occupation factors $0.663(3), 0.190(5)$ and $0.147(5)$ for O21W, O22W and O23W, respectively.

Table 2 Interatomic distances $(\AA)$ involving the $\mathrm{K}^{+}$and $\mathrm{Na}^{+}$ions in the structures of $\mathrm{K}_{3}(\mathrm{sac})_{3} \cdot 2 \mathrm{H}_{2} \mathrm{O}^{a}, \mathrm{Na}_{3}(\mathrm{sac})_{3} \cdot 2 \mathrm{H}_{2} \mathrm{O}^{b}$ and $\mathrm{K}_{2} \mathrm{Na}(\mathrm{sac})_{3} \cdot \mathrm{H}_{2} \mathrm{O}^{b}$. 
Compounds 1 and 3: $\quad(\mathrm{K}-\mathrm{O})_{\text {mean }} \quad 2.780$

$$
\Delta=(\mathrm{K}-\mathrm{O})_{\text {mean }}-(\mathrm{Na}-\mathrm{O})_{\text {mean }}=0.311
$$

Compounds 2 and 3: $\quad(\mathrm{Na}-\mathrm{O})_{\text {mean }} \quad 2.469$

Compounds 1 and 3: $\quad(\mathrm{K}-\mathrm{N})_{\text {mean }} \quad 3.007$

$$
\Delta /=(\mathrm{K}-\mathrm{N})_{\text {mean }}-(\mathrm{Na}-\mathrm{N})_{\text {mean }}=0.372
$$

Compounds 2 and 3: $\quad(\mathrm{Na}-\mathrm{N})_{\text {mean }} \quad 2.635$

$\mathrm{r}(\mathrm{K})^{+}=1.38 \AA \quad($ for $\mathrm{CN}=6)[16]$

$\mathrm{r}(\mathrm{Na})^{+}=1.02 \AA \quad($ for $\mathrm{CN}=6)[16]$

$$
\Delta^{\prime \prime}=\mathrm{r}(\mathrm{K})^{+}-\mathrm{r}(\mathrm{Na})^{+}=0.36
$$

Table 2 (continue) Interatomic distances $(\AA)$ involving the $\mathrm{K}^{+}$and $\mathrm{Na}^{+}$ions in the structures of $\mathrm{K}_{3}(\mathrm{sac})_{3} \cdot 2 \mathrm{H}_{2} \mathrm{O}^{a}, \mathrm{Na}_{3}(\mathrm{sac})_{3} \cdot 2 \mathrm{H}_{2} \mathrm{O}^{b}$ and $\mathrm{K}_{2} \mathrm{Na}(\mathrm{sac})_{3} \cdot \mathrm{H}_{2} \mathrm{O}^{b}$. 
$\mathrm{K}_{3}(\mathrm{sac})_{3} \cdot 2 \mathrm{H}_{2} \mathrm{O} \quad \mathrm{Na}_{3}(\mathrm{sac})_{3} \cdot 2 \mathrm{H}_{2} \mathrm{O}[3] \quad \mathrm{K}_{2} \mathrm{Na}(\mathrm{sac})_{3} \cdot \mathrm{H}_{2} \mathrm{O}[4]$

(this work)

\begin{tabular}{|c|c|c|c|}
\hline \multicolumn{4}{|c|}{ Bond lengths } \\
\hline \multicolumn{4}{|l|}{ Anion 1} \\
\hline $\mathrm{C}-\mathrm{O}$ & $1.234(3)$ & $1.230(3)$ & $1.227(5)$ \\
\hline $\mathrm{C}-\mathrm{N}$ & $1.360(3)$ & $1.354(3)$ & $1.351(5)$ \\
\hline $\mathrm{S}-\mathrm{N}$ & $1.607(2)$ & $1.596(2)$ & $1.596(5)$ \\
\hline $\mathrm{C}-\mathrm{S}$ & $1.766(3)$ & $1.764(2)$ & $1.760(5)$ \\
\hline \multirow[t]{2}{*}{$\mathrm{S}-\mathrm{O}$} & $1.446(2)$ & $1.443(2)$ & $1.432(3)$ \\
\hline & $1.453(2)$ & $1.450(2)$ & $1.440(3)$ \\
\hline \multicolumn{4}{|l|}{ Anion 2} \\
\hline $\mathrm{C}-\mathrm{O}$ & $1.236(3)$ & $1.241(4)$ & $1.237(4)$ \\
\hline $\mathrm{C}-\mathrm{N}$ & $1.355(4)$ & $1.346(3)$ & $1.348(5)$ \\
\hline $\mathrm{S}-\mathrm{N}$ & $1.599(3)$ & $1.606(2)$ & $1.604(5)$ \\
\hline $\mathrm{C}-\mathrm{S}$ & $1.766(3)$ & $1.767(2)$ & $1.753(5)$ \\
\hline \multirow[t]{2}{*}{$\mathrm{S}-\mathrm{O}$} & $1.453(2)$ & $1.446(2)$ & $1.444(3)$ \\
\hline & $1.439(2)$ & $1.456(2)$ & $1.440(3)$ \\
\hline \multicolumn{4}{|l|}{ Anion 3} \\
\hline $\mathrm{C}-\mathrm{O}$ & $1.239(3)$ & $1.237(3)$ & $1.244(4)$ \\
\hline $\mathrm{C}-\mathrm{N}$ & $1.355(4)$ & $1.357(4)$ & $1.353(4)$ \\
\hline $\mathrm{S}-\mathrm{N}$ & $1.601(2)$ & $1.603(2)$ & $1.608(4)$ \\
\hline $\mathrm{C}-\mathrm{S}$ & $1.765(3)$ & $1.764(3)$ & $1.770(5)$ \\
\hline \multirow[t]{2}{*}{$\mathrm{S}-\mathrm{O}$} & $1.448(2)$ & $1.445(2)$ & $1.441(4)$ \\
\hline & $1.442(2)$ & $1.455(2)$ & $1.433(4)$ \\
\hline \multicolumn{4}{|c|}{ Bond angles } \\
\hline \multicolumn{4}{|l|}{ Anion 1} \\
\hline $\mathrm{C}-\mathrm{C}-\mathrm{N}$ & $113.2(2)$ & $113.0(2)$ & $113.2(3)$ \\
\hline $\mathrm{C}-\mathrm{N}-\mathrm{S}$ & $110.9(2)$ & $111.4(2)$ & $111.2(3)$ \\
\hline $\mathrm{C}-\mathrm{S}-\mathrm{N}$ & $98.1(1)$ & $97.9(1)$ & $97.7(2)$ \\
\hline $\mathrm{O}-\mathrm{S}-\mathrm{O}$ & $114.0(2)$ & $112.9(1)$ & $112.4(2)$ \\
\hline \multicolumn{4}{|l|}{ Anion 2} \\
\hline $\mathrm{C}-\mathrm{C}-\mathrm{N}$ & $112.7(2)$ & $113.7(2)$ & $113.8(3)$ \\
\hline $\mathrm{C}-\mathrm{N}-\mathrm{S}$ & $111.6(2)$ & $111.3(2)$ & $110.8(3)$ \\
\hline $\mathrm{C}-\mathrm{S}-\mathrm{N}$ & $97.8(1)$ & $97.5(1)$ & $97.8(2)$ \\
\hline $\mathrm{O}-\mathrm{S}-\mathrm{O}$ & $113.3(1)$ & $113.9(1)$ & $112.8(2)$ \\
\hline \multicolumn{4}{|l|}{ Anion 3} \\
\hline $\mathrm{C}-\mathrm{C}-\mathrm{N}$ & $113.3(2)$ & $113.5(2)$ & $113.5(3)$ \\
\hline $\mathrm{C}-\mathrm{N}-\mathrm{S}$ & $111.1(2)$ & $111.0(2)$ & $111.3(3)$ \\
\hline $\mathrm{C}-\mathrm{S}-\mathrm{N}$ & $97.8(1)$ & $97.8(1)$ & $97.2(2)$ \\
\hline $\mathrm{O}-\mathrm{S}-\mathrm{O}$ & $113.6(1)$ & $114.0(1)$ & $114.9(3)$ \\
\hline
\end{tabular}

Table 3 Selected bond lengths $(\AA)$ and angles $\left(^{\circ}\right)$ in the saccharinato ions for $\mathrm{K}_{3}(\mathrm{sac})_{3} \cdot 2 \mathrm{H}_{2} \mathrm{O}$, $\mathrm{Na}_{3}(\mathrm{sac})_{3} \cdot 2 \mathrm{H}_{2} \mathrm{O}$ and $\mathrm{K}_{2} \mathrm{Na}(\mathrm{sac})_{3} \cdot \mathrm{H}_{2} \mathrm{O}$. 


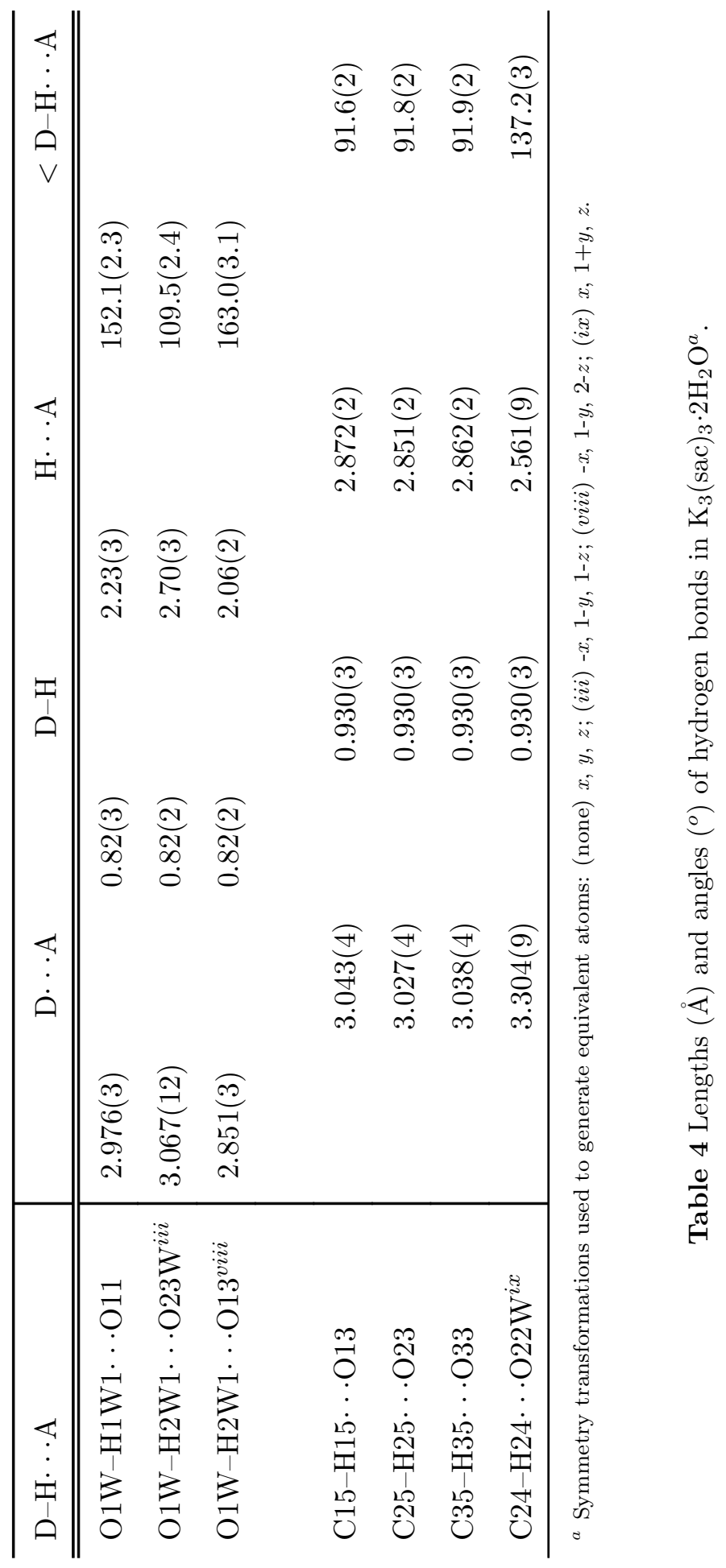




\begin{tabular}{|c|c|c|c|c|c|c|c|c|c|}
\hline \multirow{3}{*}{ No } & \multicolumn{3}{|c|}{ Experimental } & \multicolumn{5}{|c|}{ Ab initio } & \multirow{3}{*}{$\begin{array}{l}\text { Approximate } \\
\text { assignment }^{e}\end{array}$} \\
\hline & \multicolumn{2}{|c|}{ Infrared } & \multirow{2}{*}{$\begin{array}{c}\text { Raman } \\
\text { RT }\end{array}$} & \multirow[t]{2}{*}{ Binev } & \multirow{2}{*}{$\begin{array}{l}\text { et al. }[17] \\
\qquad A^{b}\end{array}$} & \multicolumn{3}{|c|}{ Naumov, Jovanovski [9] } & \\
\hline & $\mathrm{RT}$ & LNT & & & & & $A^{c}$ & $R^{d}$ & \\
\hline 1 & & $1665 \mathrm{sh}$ & & & & & & & $\nu\left(\mathrm{H}_{2} O\right)^{f}$ \\
\hline 2 & 1650 vs & $1651 \mathrm{vs}$ & $1647 \mathrm{w}$ & 1700 & 495.6 & 1691 & 94.6 & 26.2 & $\nu(\mathrm{CO})+\nu(\mathrm{CN})$ \\
\hline 3 & $1641 \mathrm{vs}$ & 1643 vs & & & & & & & $\nu\left(\mathrm{H}_{2} \mathrm{O}\right)^{f}$ \\
\hline 4 & & $1637 \mathrm{sh}$ & $1636 \mathrm{w}$ & & & & & & $\nu\left(\mathrm{H}_{2} \mathrm{O}\right)^{f}$ \\
\hline 5 & & $1626 \mathrm{sh}$ & & & & & & & \\
\hline 6 & $1587 \mathrm{~s}$ & $1589 \mathrm{~s}$ & $1595 \mathrm{~m}$ & 1596 & 17.7 & 1599 & 50.8 & 175.9 & $\nu(\mathrm{CC})+\delta(\mathrm{CCC})$ \\
\hline 7 & $1543 \mathrm{vw}$ & $1546 \mathrm{vw}$ & & 1584 & 13.8 & 1585 & 36.9 & 89.0 & $\nu(\mathrm{CC})+\delta(\mathrm{CCC})$ \\
\hline 8 & $1508 \mathrm{vw}$ & $1508 \mathrm{vw}$ & & & & & & & \\
\hline 9 & & $1498 \mathrm{vw}$ & & & & & & & \\
\hline 10 & & $1463 \mathrm{~m}$ & & 1468 & 4.5 & & & & $\delta(\mathrm{HCC})+\nu(\mathrm{CC})$ \\
\hline 11 & $1459 \mathrm{~m}$ & $1459 \mathrm{~m}$ & $1458 \mathrm{w}$ & 1459 & 13.2 & & & & $\delta(\mathrm{HCC})+\nu(\mathrm{CC})$ \\
\hline 12 & & $1387 \mathrm{vw}$ & & & & & & & \\
\hline 13 & & $1365 \mathrm{sh}$ & & & & 1366 & 35.0 & 59.4 & $\delta(\mathrm{HCC})+\nu(\mathrm{CC})$ \\
\hline 14 & & $1345 \mathrm{sh}$ & & & & & & & $\delta(\mathrm{HCC})+\delta(\mathrm{SCC})$ \\
\hline 15 & $1332 \mathrm{~s}$ & $1333 \mathrm{~s}$ & $1331 \mathrm{w}$ & & & & & & $\delta(\mathrm{HCC})+\nu(\mathrm{CC})$ \\
\hline 16 & $1288 \mathrm{~s}$ & $1289 \mathrm{~s}$ & $1292 \mathrm{w}$ & 1285 & 9.5 & & & & Benzenoid $^{g}$ \\
\hline 17 & 1255 vs & 1258 vs & $1257 \mathrm{w}$ & 1289 & 297.6 & 1268 & 324.7 & 8.4 & $\nu_{a s}\left(\mathrm{SO}_{2}\right)$ \\
\hline 18 & & 1250 vs & & 1246 & 46.2 & & & & $\delta(\mathrm{HCC})+\nu(\mathrm{CC})$ \\
\hline 19 & & $1213 \mathrm{sh}$ & & & & & & & \\
\hline 20 & $1164 \mathrm{~s}$ & $1165 \mathrm{~s}$ & $1166 \mathrm{~m}$ & 1201 & 450.3 & & & & $\nu(\mathrm{CN})+\delta(\mathrm{CSN})$ \\
\hline 21 & 1150 vs & 1153 vs & $1151 \mathrm{~s}$ & 1160 & 349.4 & 1115 & 656.8 & 27.1 & $\nu_{s}\left(\mathrm{SO}_{2}\right)+\delta(\mathrm{CSN})$ \\
\hline 22 & & 1144 vs & & 1135 & 2.4 & & & & $\nu(\mathrm{CC})+\delta(\mathrm{HCC})$ \\
\hline 23 & $1120 \mathrm{~s}$ & $1120 \mathrm{~s}$ & 1123 vw & 1117 & 40.9 & 1121 & 164.7 & 16.0 & $\delta(\mathrm{CCC})+\delta(\mathrm{HCC})$ \\
\hline 24 & & $1116 \mathrm{sh}$ & & & & & & & \\
\hline
\end{tabular}

${ }^{a}$ Except for columns denoted by $A$ and $R$, the data are given in $\mathrm{cm}^{-1}$; vw - very weak; w - weak; $\mathrm{m}$ - medium; $\mathrm{s}$

- strong; vs - very strong; sh - shoulder.

${ }^{b}$ IR intensities (in $\mathrm{km} \mathrm{mol}^{-1}$ ) for saccharin anion.

${ }^{c}$ IR intensities (in $\mathrm{km} \mathrm{mol}^{-1}$ ) for saccharin anion in ammonium saccharinate.

${ }^{d}$ Raman scattering activities (in $\AA^{4}$ per amu) for saccharin anion in ammonium saccharinate.

$e$ Vibrational modes: $\nu$, stretching; $\delta$, bending (all kinds of); subscripts: as, antisymmetric; s, symmetric.

$f$ Assignment based on the band intensity decreasing in the spectrum of the deuterated sample (see Figure 8).

$g$ Internal mode of the saccharinato six-membered ring.

Table 5 Assignment of the experimental frequencies in the infrared and Raman spectra of tripotassium trisaccharinate dihydrate based on the literature theoretical infrared and Raman data for deprotonated saccharin (saccharin anion) in the $1700-1100 \mathrm{~cm}^{-1}$ region $^{a}$. 


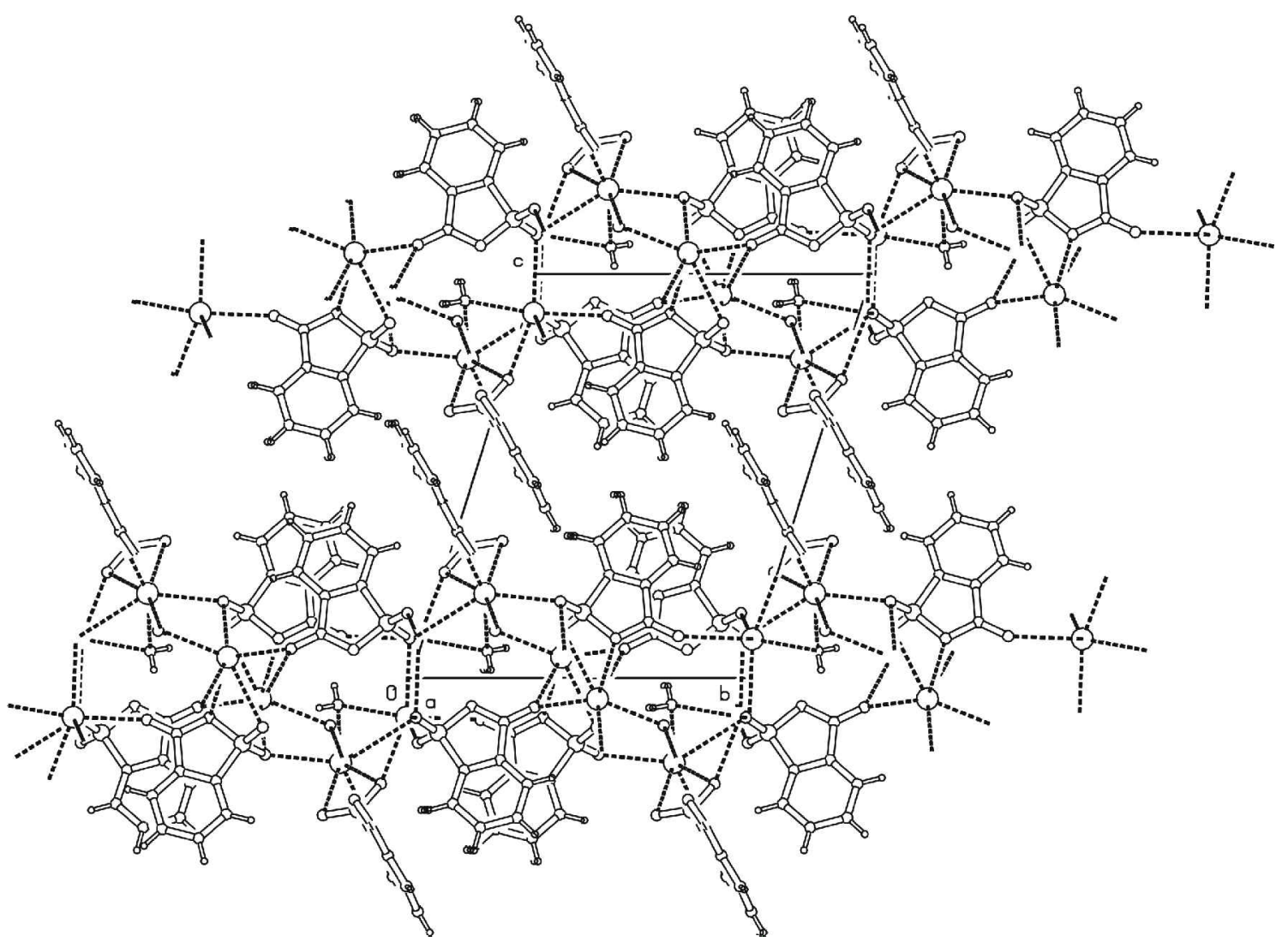

Fig. 2 The Crystal structure packing in $\mathrm{K}_{3}(\mathrm{sac})_{3} \cdot 2 \mathrm{H}_{2} \mathrm{O}$. 

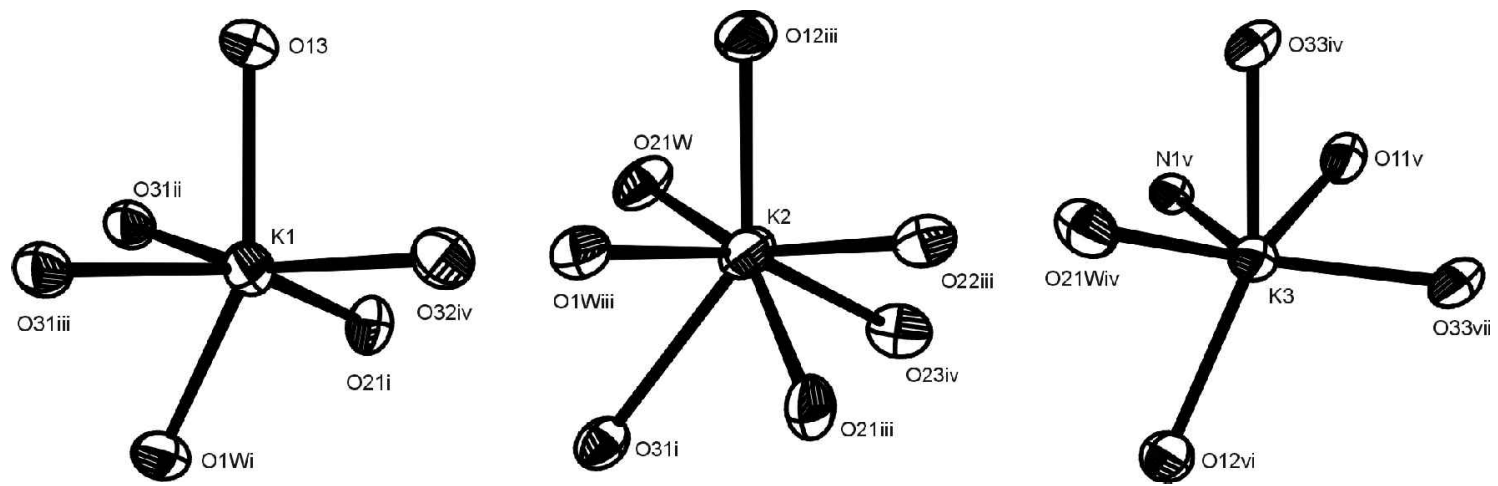

Fig. 3 The surroundings of potassium cations K1, K2 and $\mathrm{K} 3$ in $\mathrm{K}_{3}(\mathrm{sac})_{3} \cdot 2 \mathrm{H}_{2} \mathrm{O}$. The symmetry transformations are given in Table 2. In case of $\mathrm{K} 2$ and $\mathrm{K} 3$ only the oxygen atoms of the disordered water molecules, $\mathrm{O} 21 \mathrm{~W}$, with the largest occupancy (0.663) are shown. The thermal ellipsoids are drawn as ORTEP plots at $50 \%$ probability level. 


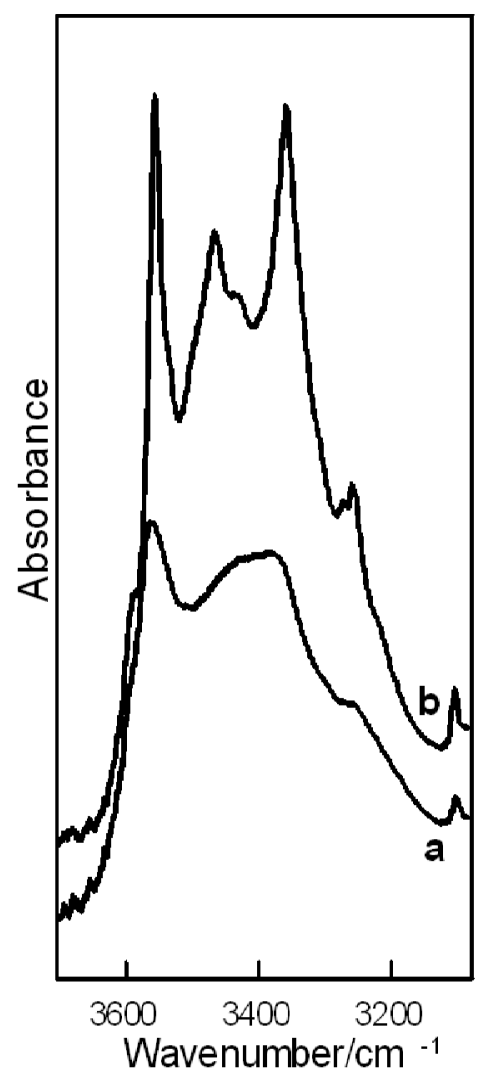

Fig. 4 The O-H stretching region in (a) RT and (b) LNT IR spectrum of $\mathrm{K}_{3}(\mathrm{sac})_{3} \cdot 2 \mathrm{H}_{2} \mathrm{O}$. 


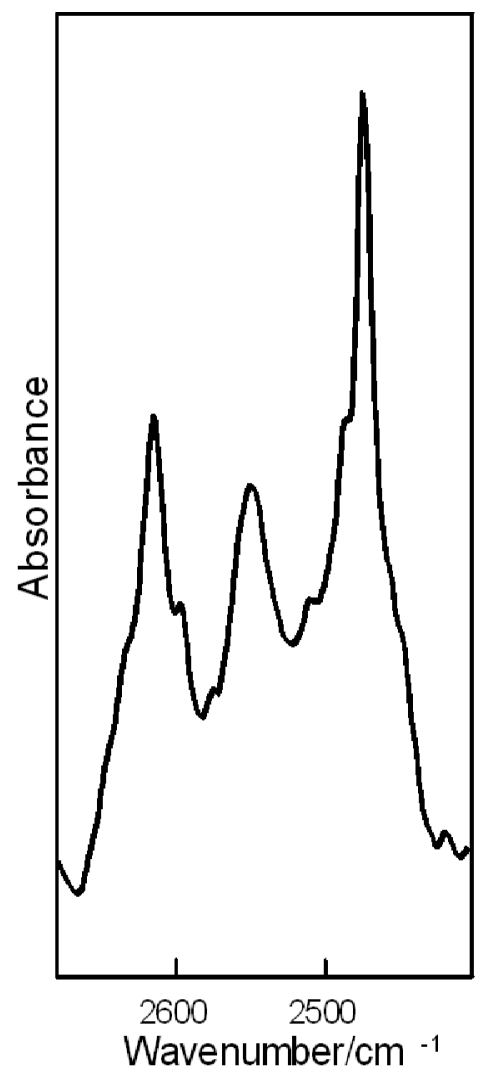

Fig. 5 The O-D stretching region in the LNT difference IR spectrum of partially deuterated analogue of $\mathrm{K}_{3}(\mathrm{sac})_{3} \cdot 2 \mathrm{H}_{2} \mathrm{O}$ (the spectrum is obtained by subtracting the LNT spectrum of the protiated species from the corresponding spectrum of the sample deuterated to $\mathrm{w}_{D} \approx 3 \%$ ). 


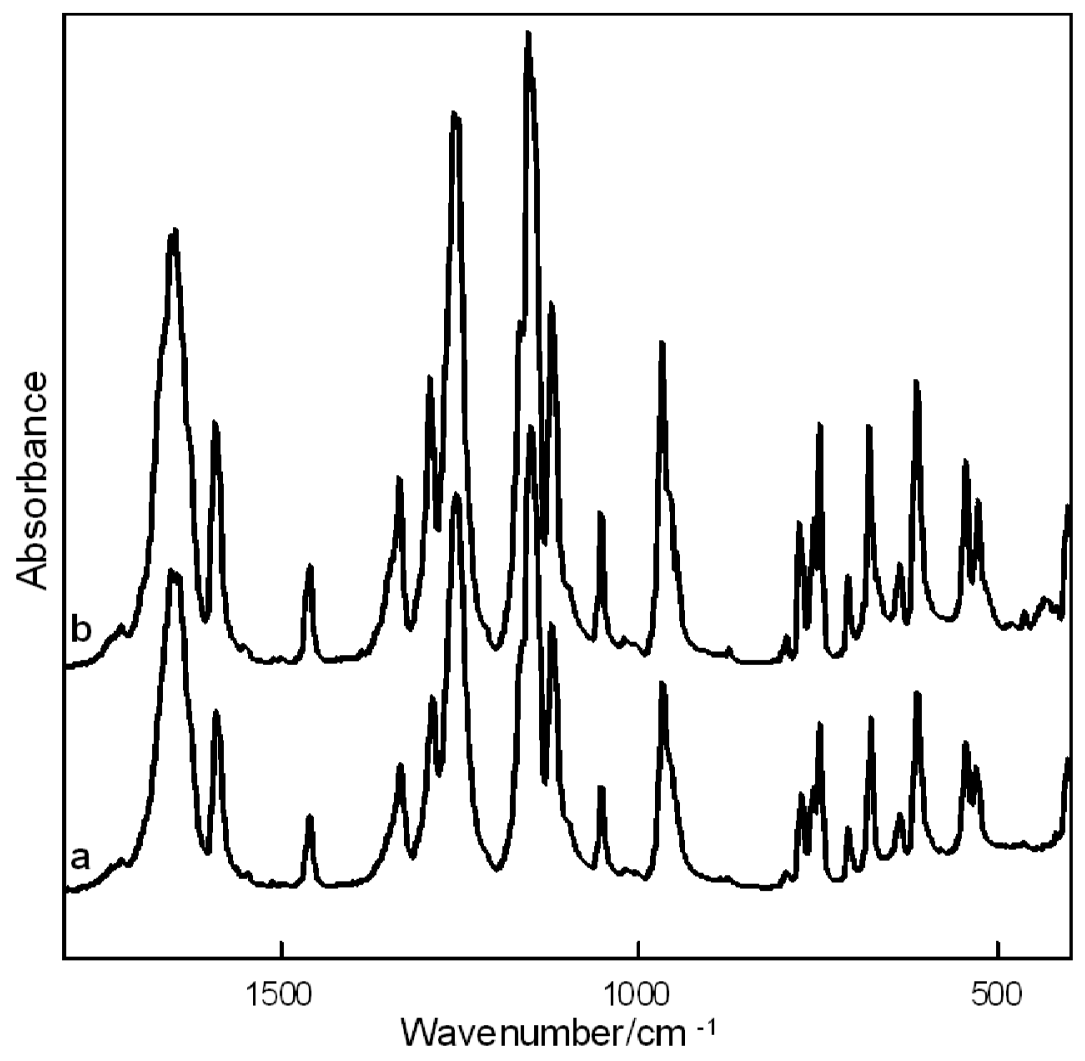

Fig. 6 The (a) RT and (b) LNT IR spectrum of $\mathrm{K}_{3}(\mathrm{sac})_{3} \cdot 2 \mathrm{H}_{2} \mathrm{O}$ in the $2000-400 \mathrm{~cm}^{-1}$ region. 


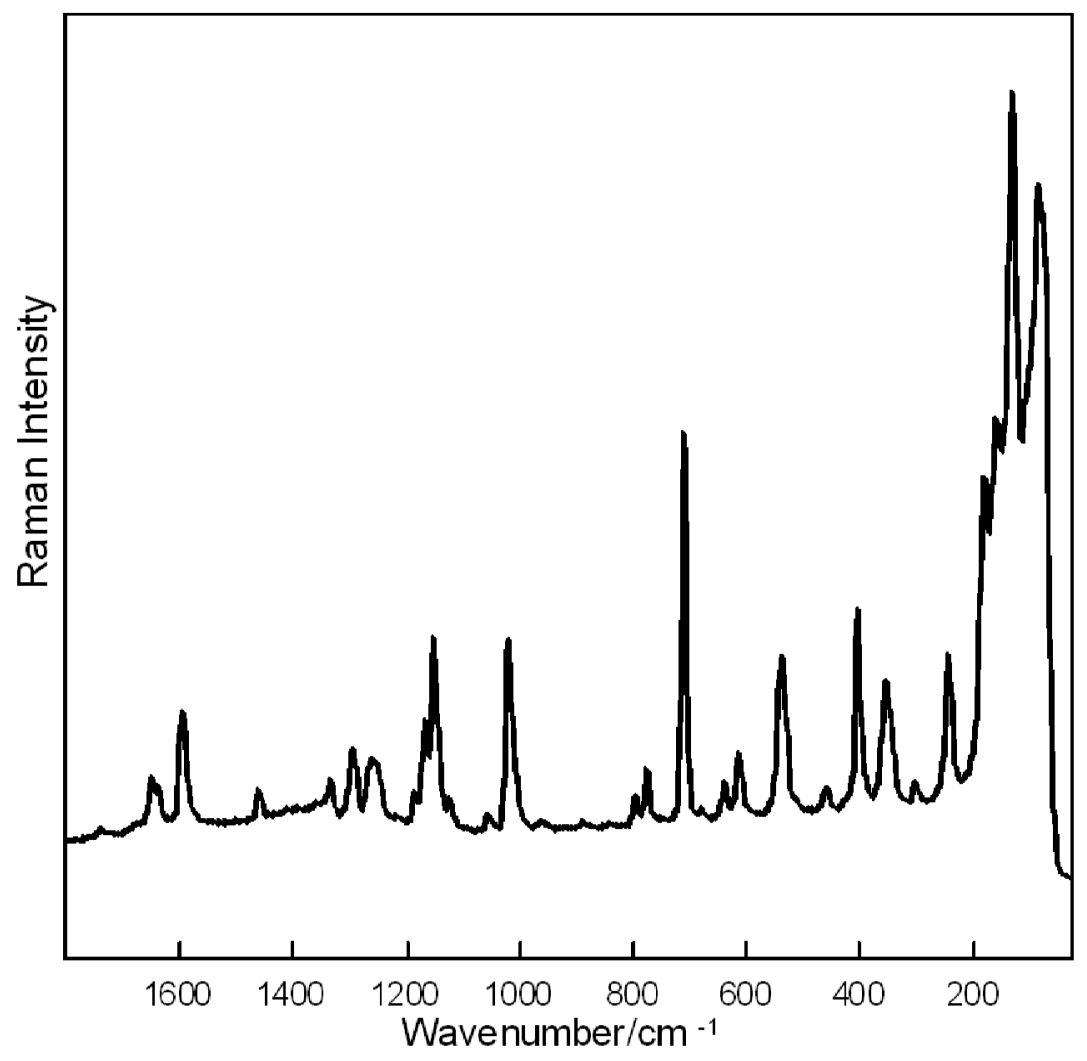

Fig. 7 The Raman spectrum of $\mathrm{K}_{3}(\mathrm{sac})_{3} \cdot 2 \mathrm{H}_{2} \mathrm{O}$ in the $1750-50 \mathrm{~cm}^{-1}$ region. 


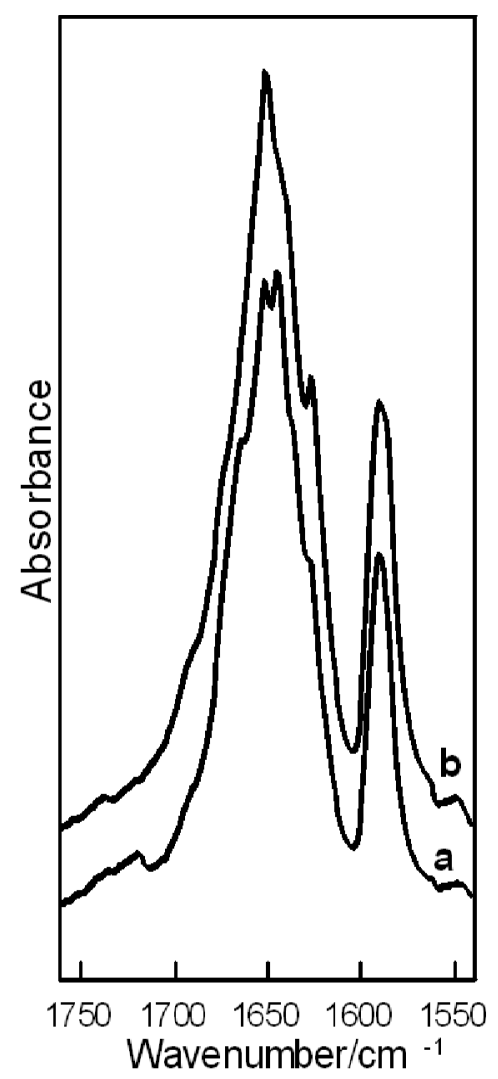

Fig. 8 The LNT IR spectrum of the (a) protiated and (b) deuterated analogue of $\mathrm{K}_{3}(\mathrm{sac})_{3} \cdot 2 \mathrm{H}_{2} \mathrm{O}$ (ca. $30 \%$ deuterium content) in the region where $\nu(C O)$ mode is expected. 